\title{
A PRODUTIVIDADE DO CONCEITO DE GÊNERO EM BAKHTIN E O CÍRCULO
}

\author{
Beth BRAIT* \\ Maria Helena Cruz PISTORI**
}

- RESUMO: No Brasil, o conceito de gênero circula de forma intensa, incluído em documentos oficiais e em materiais didáticos. Considerando a amplitude alcançada pelo arcabouço teóricoprático denominado gênero, este artigo destina-se a todos os que, na vivência profissional ligada a ensino e pesquisa, enfrentam essa realidade e se dispõem a discutir, de maneira crítica e construtiva, nuances contemporâneas desse conceito, bem como suas consequências para os meios institucionais, quer acadêmicos, escolares ou editoriais. Esse enfrentamento exige o reconhecimento de que, em suas múltiplas filiações, o conceito de gênero implica dimensões teóricas e metodológicas diferenciadas, cujas consequências para a compreensão de textos e discursos não podem ser ignoradas. Dentre as reflexões existentes, encontra-se a que foi desenvolvida por Bakhtin, Volochinov e Medvedev. Embora o ensaio "Os gêneros do discurso" seja o único difundido e utilizado em documentos e pesquisas, ele não é o único a tratar da questão. Outros trabalhos do Círculo contribuem para a concepção de gênero fundada na ideia de que a linguagem se materializa por meio de enunciados concretos, articulando "interior" e "exterior", viabilizando a noção de sujeito, histórica e socialmente situado. Essa concepção será apresentada, neste trabalho, de forma teórica e prática.

- PALAVRAS-CHAVE: Gênero do discurso. Bakhtin e o Círculo. Enunciado concreto. Texto. Discurso. Análise dialógica do discurso. Ensino.

\section{Considerações necessárias}

Gênero é um conjunto dos meios de orientação coletiva na
realidade, dirigido para seu acabamento. Essa orientação
é capaz de compreender novos aspectos da realidade.
A compreensão da realidade desenvolve-se e origina-
se no processo da comunicação social ideológica.

Medviédev (2012, p.200).

* Bolsista Produtividade CNPq. PUCSP - Pontifícia Universidade Católica de São Paulo. Departamento Linguística - Pós-graduação em Linguística Aplicada e Estudos da Linguagem. São Paulo - SP - Brasil. 05014001 - bbrait@uol.com.br

** Bolsista Pós-doc da FAPESP. PUCSP - Pontifícia Universidade Católica de São Paulo. Pós-graduação em Linguística Aplicada e Estudos da Linguagem. São Paulo - SP - Brasil. 05014-001 - mhcpistori@uol.com.br 
No Brasil, o conceito de gênero circula de forma intensa, incluído em documentos oficiais de ensino/aprendizagem e em materiais didáticos, merecendo, da parte dos que o mobilizam didática e/ou academicamente, a responsabilidade de considerar as dimensões históricas, sociais e autorais aí implicadas. Reconhecendo a amplitude alcançada pelo arcabouço teórico-prático que circunda o conceito de gênero, este artigo destina-se a todos os que, na vivência profissional ligada a ensino e pesquisa, enfrentam essa realidade e se dispõem a discutir, de maneira crítica e construtiva, nuances contemporâneas desse conceito, bem como suas consequências para os meios institucionais, quer acadêmicos, escolares ou editoriais.

Esse enfrentamento, que não é simples, em especial e de forma contundente para aqueles que estão em sala de aula, exige o reconhecimento de que, em suas múltiplas filiações, a concepção de gênero implica dimensões teóricas e metodológicas diferenciadas, cujas consequências para a compreensão de textos e discursos não podem ser ignoradas. Dentre as inúmeras e produtivas reflexões existentes, encontra-se a que foi desenvolvida ao longo de várias décadas pelos trabalhos de Mikhail Bakhtin (1895-1975) e de outros membros do Círculo, caso de Pavel N. Nikolaevich Medvedev (1892-1938) e Valentin Nikilaevič Volochinov (1895-1936). ${ }^{1}$

Embora o ensaio mais conhecido, citado e tomado como único seja "Os gêneros do discurso", esboçado por Bakhtin nos anos 1950 e incluído na coletânea póstuma Estética da criação verbal (BAKHTIN, 2003a, p.261-306), esse não é o único a tratar da questão. Outros trabalhos de Bakhtin, escritos e/ou publicados nos anos 1920, 30 e 40, tratam da questão dos gêneros do discurso. Esse é o caso de: "O problema do conteúdo, do material e da forma na criação literária”, escrito entre 1923/1924 e inserido na coletânea Questões de literatura e de estética - A teoria do romance, publicada em 1975 (BAKHTIN, 1988a, p.45-70), trabalho que discute, dentre outras coisas, um aspecto essencial à concepção do gênero: a diferença entre forma composicional e forma arquitetônica; Problemas da poética de Dostoiévski, inteiramente dedicado ao gênero romance polifônico, cuja primeira edição, intitulada Problemas da obra de Dostoiévski, é de 1929, e a segunda, modificada e aumentada, Problemas da poética de Dostoiévski, é de 1963; "O discurso no romance”, produzido entre 1934-1935, também inserido em Questões de literatura e de estética - A teoria do romance (BAKHTIN, 1988b, p.71-210), que recoloca a questão do gênero do discurso, apresentando e discutindo importantes aspectos acerca da ligação existente entre língua, gêneros e estilo.

O nome de Valentin Nikilaevič Vološinov aparece de diferentes formas nas diferentes edições consultadas. Adotamos, ao longo do texto, a grafia da capa da edição brasileira de 1997 - Volochinov. Nas referências finais, respeitamos a grafia da edição consultada. 
Ainda nos anos 1920, outros dois membros do Círculo se interessam pela questão do gênero. Medvedev, na obra O método formal nos estudos literários - Uma introdução crítica a uma poética sociológica no capítulo "Os elementos da construção artística/O problema do gênero", contribui para uma concepção de gênero fundada na ideia de que a linguagem se materializa por meio de enunciados concretos, articulando "interior" e "exterior", viabilizando a noção de sujeito histórica e socialmente situado. Volochinov, por sua vez, em Marxismo e filosofia da linguagem - Problemas fundamentais do método sociológico na ciência da linguagem, publicado em 1929, de forma explícita em dois capítulos: "Relação entre infraestrutura e superestruturas", em que aparece a articulação entre formas e temas de cada ato de fala e o atrelamento às condições e tipos de comunicação verbal - os gêneros, e "A interação verbal", em que retoma a questão das categorias dos atos de fala e sua ligação com a criação ideológica - o diálogo ininterrupto na cadeia de comunicação verbal em seus vários tipos, prometendo aprofundar a reflexão em outro trabalho. De fato, no artigo intitulado "A construção do enunciado/ enunciação", publicado em 1930, refere-se novamente aos tipos de enunciados comunicativos a que denomina gêneros.

O objetivo deste artigo, por essas razões, é considerar que o conceito de gênero não se reduz a uma caracterização do discurso por meio dos três termos conhecidos e reconhecidos a partir da leitura do texto de Bakhtin "Os gêneros do discurso" - tema, composição e estilo -, trabalho que não será objeto deste artigo por ser largamente conhecido: a concepção de gênero vai sendo construída ao longo dos trabalhos do Círculo, como resposta a outras tendências dos estudos da linguagem que, de alguma forma, se interessaram pelo tema. A estudiosa brasileira Irene Machado explicita de maneira muito apropriada um dos aspectos do gênero que este artigo pretende focalizar: "O estatuto dos gêneros literários se consolidou e nada teria abalado seus domínios se o imperativo típico da época de Aristóteles tivesse se perpetrado, quer dizer, se não houvesse surgido a prosa comunicativa." (MACHADO, 2005, p.152).

A autora afirma, e sem isso não há possibilidade de compreensão de gênero, conforme concebida pelo Círculo, que "[...] de modo geral, a emergência da prosa passou a reivindicar outros parâmetros de análise das formas interativas que se realizam pelo discurso." (MACHADO, 2005, p.152).

Ainda que não seja uma discussão exaustiva, a ideia é mostrar como o conceito de gênero do discurso vai se construindo em cada trabalho do Círculo, de modo a se perceber: (i) os interlocutores envolvidos, ou seja, a tendência dos estudos da linguagem que possibilita o diálogo em torno desse conceito; (ii) o conceito aí produzido e suas características; (iii) a fundamentação teórica e metodológica envolvida na conceituação. 
A questão da autoria, não solucionada e motivadora de polêmicas e infrutíferos debates, neste artigo, obedecendo à tendência implantada pelos primeiros bakhtinianos brasileiros, e explicitada em vários trabalhos, será indicada conforme aparece na publicação/tradução utilizada. Ainda uma observação necessária: é impossível pensar ou assumir a postura do Círculo diante da questão do gênero sem, necessariamente, levar em conta outros conceitos a ele ligados, caso de linguagem, signo ideológico, enunciado concreto, texto, discurso/ relações dialógicas, forma arquitetônica, forças centrípetas e forças centrífugas, dentre outros.

Para finalizar, apresenta-se a análise de uma página de jornal, constituída por vários gêneros, tendo como foco o ensino e considerando as propostas sobre gênero trabalhadas pelo hoje denominado pensamento bakhtiniano, que envolve vários pensadores.

\section{Problemas da poética de Dostoiévski: um estudo de gênero}

O gênero sempre é e não é o mesmo, sempre é velho e novo ao mesmo tempo

O gênero vive do presente mas sempre recorda o seu passado, o seu começo. Bakhtin (2008, p.121).

A maioria dos leitores que se socorre do conceito de gênero, especialmente para salvar o ensino no que se refere à leitura e produção de textos, em algum momento se depara com (ou é a ele dirigido) o clássico "Os gêneros do discurso", trabalho de Bakhtin, escrito entre 1951-53, que aparece na coletânea cuja primeira edição russa é de 1979, e que está ao alcance dos brasileiros na cuidadosa tradução de Paulo Bezerra. Em geral, a maioria desses leitores acaba entendendo gênero do discurso como uma fórmula mágica, reduzida exclusivamente a três elementos: forma de composição, conteúdo temático e estilo, concluindo que, uma vez aplicada, essa receita dará conta da compreensão e ensino de gêneros e, consequentemente, da leitura e produção de textos.

O que se desconsidera com essa atitude é que tanto os textos de forma geral, quanto o conceito de gênero produzido pelo pensamento bakhtiniano, são frutos de um contexto, de uma época, de uma maneira de conceber conhecimento, linguagem, relação homem-mundo. Ler, nesse mesmo ensaio, a distinção entre oração e enunciado, por exemplo, traria inúmeros benefícios para a compreensão 
de que Bakhtin, ao formular a questão dos gêneros do discurso, não trata exclusivamente da literatura e nem abandona as questões postas pela linguística, ampliadas com a consideração da relação entre linguagem e comunicação, linguagem e vida. Para compreender essa questão, a leitura de Problemas da poética de Dostoiévski é fundamental.

Em sua segunda edição (1963), logo no início do primeiro capítulo, o leitor (especialmente o linguista e o analista de discurso), ao se deparar com a afirmação de que "Dostoiévski é o criador do romance polifônico. Criou um gênero romanesco essencialmente novo" (BAKHTIN, 2008, p.5), pode ter a impressão de que o conceito de gênero advindo dessa obra refere-se unicamente à literatura. Entretanto, se acompanhar essa excelente panorâmica dos estudos sobre Dostoiévski, passar pelo segundo capítulo em que a questão da personagem é detalhada, colaborando para a compreensão da questão das vozes (polifonia), chegar ao capítulo "A ideia em Dostoiévski", em que se pode ter acesso à concepção de dialogismo e polifonia, o leitor chegará ao alentado capítulo que interessa muito de perto a todos os estudiosos de gênero: "Peculiaridades do gênero, do enredo e da composição das obras de Dostoiévski." (BAKHTIN, 2008, p.52-206). Nele, Bakhtin vai tratar especificamente dos gêneros carnavalizados e, para isso, anuncia a relação existente entre gênero literário sério-cômico, diálogo socrático e sátira menipeia, por exemplo, com folclore carnavalesco, esmiuçando particularidades desses dois gêneros, tratando dos gêneros intercalados (novelas, cartas, discursos oratórios, simpósios, etc.), demonstrando que os gêneros carnavalizados influenciaram a literatura e a cultura.

Num determinado momento, Bakhtin (2008, p.136, grifo do autor) afirma que: "O parentesco entre esses gêneros [diatribe, solilóquio e simpósio, incorporados pela menipeia] é determinado pelo seu caráter dialógico interno e externo no enfoque da vida e do pensamento humanos." Esse caráter dialógico interno e externo no enfoque da vida e do pensamento humanos é muito importante para a compreensão do gênero do discurso no conjunto das obras do Círculo: o conceito de gênero não se limita a estruturas ou textos, embora os considere como dimensões constituintes. Implica, essencialmente, dialogismo e maneira de entender e enfrentar a vida. E o autor vai, visando à dimensão interna/externa, analisar detidamente as obras de Dostoiévski e insistir em outra ideia fundamental: a importância de se considerar a tradição em que um dado gênero se insere. Segundo essa abordagem teórico-metodológica, nenhum gênero surge do nada: ele se liga necessariamente a uma tradição. É essa tradição que permite estudar qualquer gênero do ponto de vista diacrônico (os gêneros que o antecedem, aos quais ele se liga e ao mesmo tempo modifica) e sincrônico (características pertencentes aos gêneros antecedentes e, ao mesmo tempo, as novas características que o definem e diferenciam dos antecessores). 
Se as questões sinalizadas até aqui parecem suficientes para demonstrar que a questão do gênero está no centro da obra Problemas da poética de Dostoiévski, resultando num minucioso estudo sobre um gênero específico, romance polifônico, é o quinto capítulo "O discurso em Dostoiévski" (BAKHTIN, 2008, p.207-310), subdividido em quatro partes, que ajuda a entender ao menos mais duas coisas: de um lado, que o conceito de gênero em Bakhtin não se limita às produções literárias; de outro, mas inteiramente ligado ao primeiro, que há uma necessária articulação entre gênero e discurso.

Ao iniciar o capítulo com o subitem "Algumas observações metodológicas prévias", o autor afirma: "Intitulamos este capítulo 'O discurso em Dostoiévski' porque temos em vista o discurso, ou seja, a língua em sua integridade concreta e viva" (BAKHTIN, 2008, p.207). A partir daí vai propor a Metalinguística que, juntamente com a Linguística, estudaria o objeto multifacetado que é o discurso. Esse objeto, também denominado "relações dialógicas", está diretamente ligado ao exame do discurso do ponto de vista da sua relação com o discurso do outro e com a compreensão da prosa literária, na medida em que, como afirma Bakhtin,

\begin{abstract}
Ao analisarmos a prosa, nós mesmos nos orientamos muito sutilmente entre todos os tipos e variedades de discurso que examinamos. Além disso, na prática cotidiana, ouvimos de modo muito sensível e sutil todas essas nuanças nos discursos daqueles que nos rodeiam, nós mesmos trabalhamos muito bem com todas essas cores da nossa paleta verbal. Percebemos de modo muito sensível o mais ínfimo deslocamento da entonação, a mais leve descontinuidade de vozes no discurso cotidiano do outro, essencial para nós. Todas essas precauções verbais, ressalvas, evasivas, insinuações e ataques são registrados pelos nossos ouvidos e são familiares aos nossos próprios lábios. (BAKHTIN, 2008, p.231).
\end{abstract}

Essa perspectiva é fundamental para entender que a questão do gênero para o Círculo, e não apenas para Bakhtin, tem a ver com o advento da prosa literária, diferentemente do estudo de gêneros proposto por Aristóteles (MACHADO, 2005). É a prosa literária que vai ouvir e se nutrir da fala cotidiana e dos gêneros que a constituem.

A conclusão de Problemas da poética de Dostoiévski traz, além do estudo inédito e exaustivo sobre o gênero romance polifônico, importantes afirmações sobre gênero que respondem questões colocadas hoje em relação aos gêneros próprios das novas formas de comunicação, viabilizadas pela tecnologia e, especialmente, por novos valores assumidos pelo homem contemporâneo em relação a tempo/espaço, público/privado, efêmero/duradouro:

Ao nascer, um novo gênero nunca suprime nem substitui quaisquer gêneros já existentes. Qualquer gênero novo nada mais faz que 
completar os velhos, apenas amplia o círculo de gêneros já existentes. Ora, cada gênero tem seu campo predominante de existência em relação ao qual é insubstituível [...] Ao mesmo tempo, porém, cada novo gênero essencial e importante, uma vez surgido, influencia todo o círculo de gêneros velhos: o novo gênero torna os velhos, por assim dizer, mais conscientes, fá-los melhor conscientizar os seus recursos e limitações, ou seja, superar a sua ingenuidade. (BAKHTIN, 2008, p.340, grifo nosso).

Não seria esse um importante ponto de partida para estudar o e-mail, o blog, o twitter, os chats, dentre outros gêneros, captando sua atualidade, sua inovação, sua dimensão individual e coletiva, e, ao mesmo tempo, a inserção numa tradição ligada ao gênero correspondência e/ou diário íntimo/ público? Estudados isoladamente, eles podem ser entendidos a partir de sua estrutura, das exigências do suporte, dos avanços tecnológicos; mas no corpo da tradição a que pertencem, certamente dirão muito mais sobre os sujeitos que os utilizam e neles se constituem, sobre a sociedade atual e suas formas de enfrentar a vida.

\section{O conceito de gênero e "O problema do conteúdo, do material e da forma"}

Antes da publicação da primeira edição de Problemas da poética de Dostoiévski (1929), Bakhtin havia escrito um trabalho intitulado "O problema do conteúdo, do material e da forma na criação literária" (1923/1924). Esse texto, ${ }^{2}$ como esclarece Faraco (2009a, p.96), tem como objetivo "[...] criticar o pensamento estético do formalismo russo (a que Bakhtin chama de estética material) e apresentar coordenadas básicas de uma estética geral sistemática (filosófica) a partir da qual se possa elaborar uma poética que supere a estreiteza da estética material." Faraco (2009a, p.97, grifo nosso) afirma, ainda, que ele inclui "[...] algumas de suas contribuições mais relevantes para a análise da arte, da literatura e da linguagem em geral." Aspecto fundamental para se entender que os textos do Círculo, mesmo tratando de poética, podem ser ampliados para a compreensão de qualquer tipo de linguagem. Faraco sugere que, por se relacionar com todos os trabalhos de Bakhtin e dos demais membros do Círculo, deve ser lido com outros textos, especialmente "Arte e responsabilidade" (BAKHTIN, 2003), Para uma filosofia do ato (BAKHTIN, 2010) "O autor e a personagem na atividade estética" (BAKHTIN, 2003) e O método formal nos estudos literários:uma introdução crítica a uma poética sociológica (MEDVIÉDVE, 2012).

Como esse texto, dos anos 1920, contribui para o conceito de gênero?

\footnotetext{
2 Ver, a respeito desse ensaio, o excelente texto de Carlos Alberto Faraco (2009b), que optou pelo título "O
} problema do conteúdo, do material e da forma verbal", a partir da edição em língua inglesa (BAKHTIN, 1990). 
O aspecto que deve ser aproveitado para a discussão de gênero do discurso é o que se refere à diferença entre forma composicional e forma arquitetônica. Para chegar a essa distinção, Bakhtin sugere que é preciso enfrentar a unidade do texto não como dada exclusivamente por sua forma externa, aparentemente autônoma, mas por seu plano, ou seja, por suas condições concretas de vida, suas interdependências, suas relações, suas posições dialógicas e valorativas. Esse plano ele denomina forma arquitetônica, aspecto que tem a ver, em termos do conjunto da proposta do pensamento bakhtiniano, com a relação eu para o outro - o outro para mim, presente nos textos, nos discursos, nos gêneros:

Deve-se ter em vista que cada forma arquitetônica é realizada por meio de métodos composicionais definidos; por outro lado, às formas composicionais mais importantes, às de gênero por exemplo, correspondem, no objeto realizado, formas arquitetônicas essenciais. (BAKHTIN, 1988a, p.24).

O que se depreende desse texto, portanto, e que tem fundamental importância para o conceito de gênero, no conjunto da obra do Círculo e para sua mobilização teórico-metodológica hoje, é que o estudo do gênero deve levar em conta uma concepção de texto que considere, necessariamente, a forma arquitetônica. Embora esse seja um conceito difícil, que se diferencia de forma composicional, mas não o exclui, o analista de gênero, que se coloca na perspectiva dialógica, deve se apropriar dele. De maneira simplificada, pode se dizer que, diante de um gênero, e dos textos que o constituem, é necessário considerar suas dimensões (interna/externa), de maneira a explicitar as inter-relações dialógicas e valorativas (entoativas, axiológicas) que o caracterizam enquanto possibilidade de compreender a vida, a sociedade, e a elas responder. Esse movimento amplo, e não apenas descritor das estruturas, da forma composicional, visa justamente à forma arquitetônica do gênero, do texto, dos textos. Como explicita Faraco, é a forma arquitetônica que governa a construção da massa verbal, a construção da forma composicional, incluindo a seleção do material verbal pensado como linguagem situada (FARACO, 2009a, p.109).

Ao estudar, por exemplo, o editorial, com o objetivo de ensinar quais são as características desse gênero, é possível considerar somente sua forma composicional (sua forma dissertativa predominante), ou trabalhar a forma arquitetônica que o constitui e que dará ao aluno condições de compreender o gênero, dominá-lo e produzi-lo como sujeito/autor, consciente das condições de produção, circulação e recepção de um editorial. Na segunda opção, tornase obrigatório: a) localizar editorial no jornal em que foi publicado (veículo, suporte, tempo, espaço, etc.) e não apenas recortá-lo e tirá-lo de sua situação de produção, circulação e recepção; b) especificar a seção e o caderno em que ele aparece (tratando-se de imprensa escrita), comparando com outros jornais 
que também têm editoriais, levando o aluno a perceber que esse não é um texto autônomo, mas faz parte dos gêneros jornalísticos e/ou opinativos que caracterizam a imprensa contemporânea; c) levar o aluno a observar os demais textos que participam da página em que o editorial se encontra, estabelecendo as relações existentes entre eles; d) levar o aluno, ainda, a observar o conjunto das matérias publicadas no jornal, naquele dia e em anteriores/posteriores, e a maneira como o editorial se relaciona com elas, nesse e nos jornais imediatamente anteriores/posteriores; e) chamar a atenção do aluno para ao menos três outras coisas: 1) o jornal (escrito) tem um projeto gráfico no qual o editorial ocupa um espaço específico, cuja função é situar o leitor e destacar seu papel, enquanto gênero diante de outras matérias; 2) como todos os demais gêneros, o editorial possibilita a compreensão de um dado aspecto da vida, de forma diferenciada de outros gêneros, mas tendo em comum com eles o fato de refletir e refratar um acontecimento, um evento; e 3) o editorial, enquanto gênero, insere-se na tradição dos gêneros jornalísticos opinativos, marcada, portanto, por um estilo do gênero, que é mais amplo que o estilo do jornal e do jornalista que "assina" o texto. Para esse refinamento final, o texto estudado, também em sua dimensão interna (forma composicional, estilo etc.), tem de ser comparado a outros editoriais e às posições aí implicadas.

Com isso, o aluno saberá que, para construir um editorial, terá de considerar muito mais coisas (veículo, público, suporte, destinatários, posição diante de um fato, articulada à posição do jornal, etc.) que para a construção de um texto dissertativo opinativo ideal, deslocado de acontecimentos, tempo, espaço, coerções comunicativas. Terá de ser sujeito de seu discurso, articulado com as coerções do jornal/veículo/suporte em que seu editorial se insere.

\section{O conceito de gênero em "O discurso no romance"}

Esse texto, escrito em 1934-1935, faz parte de um conjunto de trabalhos em que o romance é objeto de estudo, concebido como gênero cuja característica básica é ser um "fenômeno pluriestilístico, plurilíngue e plurivocal" (BAKHTIN, 1988b, p.73). Dividido em cinco partes, revela-se como mais um trabalho de fôlego em que um gênero é objeto de estudo detalhado. Embora mais uma vez o leitor possa imaginar que a discussão só interesse ao estudioso da literatura, vai descobrir que, de maneira explícita, questões sobre a linguagem em geral e sobre a possibilidade de expandir a reflexão para outros gêneros podem ser aí apreendidas. Com o objetivo de demonstrar as fortes relações que o romance mantém com os gêneros não literários e como é possível traçar a "história do romance" a partir dessas relações, Bakhtin apresenta importantes questões de língua, linguagem, variedade linguística, estratificação da língua em gêneros, variedade de gêneros. 
Juntamente com o propósito de estudar um gênero distanciando-se da ruptura entre o "formalismo" e o "ideologismo" abstratos, Bakhtin dedica amplo espaço à articulação existente entre língua, gêneros e estilo. Esse aspecto, que redunda em significativos ganhos para uma concepção dinâmica de língua, linguagem e estudo de gêneros, sublinha a característica definidora do romance, que tem a ver com a unidade/multiplicidade que constitui uma língua em qualquer estágio de sua existência, dando a Bakhtin a oportunidade de trazer à tona pertinentes questões sobre língua, linguagem e discutir importantes conceitos para os estudos de língua e discurso, caso de estratificação interna, dialetos sociais, linguagens de gêneros, forças centrípetas, forças centrífugas, plurilinguismo, vozes, linguagem estratificada em gêneros, dentre outras dimensões que constituem e regem a língua em uso, das quais o gênero romance se alimenta:

A estratificação interna de uma língua nacional única em dialetos sociais, maneirismos de grupos, jargões profissionais, linguagens de gêneros, fala das gerações, das idades, das tendências, das autoridades, dos círculos e das modas passageiras, das linguagens de certos dias e mesmo de certas horas (cada dia tem sua palavra de ordem, seu vocabulário, seus acentos), enfim, toda estratificação interna de cada língua em cada momento dado de sua existência histórica constitui premissa indispensável do gênero romanesco. E é graças a este plurilinguismo social e ao crescimento em seu solo de vozes diferentes que o romance orquestra todos os seus temas, todo seu mundo objetal, semântico, figurativo e expressivo. (BAKHTIN, 1988b, p.74).

Nesse texto, portanto, é possível encontrar ideias que hoje são mobilizadas pela Sociolinguística, pela Linguística Aplicada, pelas diferentes teorias e análises de discurso, as quais têm a ver com uma postura histórica, social, diante das linguagens, da/s língua/s e dos sujeitos. Esse é o caso das forças centrípetas e forças centrífugas que regem a linguagem. $O$ autor demonstra que a tensão contínua entre essas duas forças engloba, dialeticamente, a questão da unidade e da heterogeneidade de uma língua, evidenciando o constitutivo movimento entre unificação, centralização das ideologias verbais, orientação para a unidade e plurilinguismo real. Segundo Bakhtin,

Em cada momento da sua formação, a linguagem diferencia-se não apenas em dialetos linguísticos [...], mas o que é essencial, em línguas socioideológicas: sociogrupais, 'profissionais', 'de gêneros', etc. [...] a estratificação e o plurilinguismo ampliam-se e aprofundam-se na medida em que a língua está viva e desenvolvendo-se; ao lado das forças centrípetas caminha o trabalho contínuo das forças centrífugas da língua, ao lado da centralização verbo-ideológica e da união caminham ininterruptos os processos de descentralização e desunificação. (BAKHTIN, 1988b, p.82). 
E é a partir desse raciocínio sobre a linguagem que o autor vai entender o romance e os gêneros prosaicos, ou seja, os gêneros verbais portadores das tendências descentralizantes da vida linguística, ligados ao plurilinguismo, à pluralidade, à plurivocidade, constituídos na corrente das forças centrífugas (descentralizadoras). Esses gêneros estão diretamente associados ao dialogismo linguístico, ao aspecto dialógico do discurso e a todos os fenômenos a ele ligados. (BAKHTIN, 1988b). Ao longo dos cinco itens que compõem o trabalho, Bakhtin tece considerações sobre os gêneros ligados à estratificação da língua, à orientação dialógica do discurso para os discursos de outrem, às diferentes formas e graus da orientação dialógica, aprofundando importantes e inéditas questões sobre a linguagem viva, do dia a dia. Ao discutir as noções de estratificação e plurilinguismo em relação ao romance, por exemplo, aponta novamente para gêneros de uma maneira geral, como se observa no seguinte trecho:

Esta estratificação é determinada, antes de tudo, pelos organismos específicos dos gêneros. Estes ou aqueles elementos da língua (lexicológicos, semânticos, sintáticos, etc.) estão estreitamente unidos com a orientação intencional e com o sistema geral de acentuação destes ou daqueles gêneros: oratórios, publicitários, gêneros de imprensa [...]

Estes ou outros elementos da língua adquirem o perfume específico dos gêneros dados: eles se adéquam aos pontos de vista específicos, às atitudes, às formas de pensamento, às nuanças e às entonações desses gêneros.

Esta estratificação da língua em gêneros se entrelaça, ora coincidindo, ora divergindo, com a estratificação profissional da língua (em amplo sentido): a linguagem do advogado, do médico, do comerciante, do político, do mestre-escola, etc. Estas linguagens diferenciam-se evidentemente não só pelo vocabulário: elas implicam determinadas formas de orientação intencional, formas estas de interpretação e de apreciação concretas.

[...] Dentro destes âmbitos, isto é, para os próprios falantes, estas linguagens de gêneros e estes jargões profissionais são diretamente intencionais - plenamente significativos e espontaneamente expressivos. (BAKHTIN, 1988b, p.96-97, grifo nosso).

[...] Finalmente, deter-nos-emos ainda sobre uma das formas mais importantes e substanciais de introdução e organização do plurilingüismo no romance: os gêneros intercalados. (BAKHTIN, 1988b, p.124).

No final do trabalho, Bakhtin (1988b, p.200) afirma que "[...] o romance não foi uma enciclopédia de linguagens, mas de gêneros [...]", na medida em que está imerso na prosa do mundo, dela bebendo e nela se constituindo ${ }^{3}$. O percurso

3 Em 1940, Bakhtin escreve A cultura popular na Idade média e no Renascimento: o contexto de François Rabelais [Moscou, 1965], cujo capítulo a respeito do "vocabulário da praça pública na obra de Rabelais" dá 
esclarece sobre gêneros em prosa, forças que movimentam a língua viva, heterogeneidade e plurilinguismo, tomando o ser humano e a linguagem como parâmetros dos valores e das tensões que regem o mundo.

\section{O conceito de gênero em $O$ método formal nos estudos literários}

O método formal nos estudos literários: uma introdução crítica a uma poética sociológica, publicada na Rússia em 1928 e só agora, 2012, com uma excelente tradução para o português, tem autoria disputada e pode ser encontrada em inglês (1978), indicando como autores Bakhtin e Medvedev; em espanhol, Mijail Bajtin e Medvedev (1994); em francês, indicando Medvedev e Bakhtin (2008). Nessa obra, em que a criação artística é vista como a combinação de elementos vinculados à comunicação ideológica social e à compreensão temática da realidade (MEDVIÉDEV, 2012, p. 193-207), o capítulo “Os elementos da construção artística" ${ }^{4}$, dividido em 8 partes, trata especificamente de gênero.

O leitor não deve se enganar. Embora os títulos, da obra e do capítulo, sugiram a ideia de estudos exclusivamente literários, a discussão passa por questões fundamentais para a compreensão do gênero do discurso de forma geral. A interlocução se dá com os formalistas russos, o que significa que o leitor de hoje precisa conhecer essa forte tendência dos estudos da linguagem para compreender que, como nos demais trabalhos do Círculo, especialmente os produzidos na década de 1920, há sempre uma espécie de resposta a importantes pensadores da linguagem, cujos traços fundamentais são recuperados e problematizados a partir de uma nova visão sobre o tema. Sem entender a importância dos formalistas russos, fica difícil compreender os principais argumentos apresentados por Medvedev para fundamentar um novo conceito de gênero. ${ }^{5}$

Ao afirmar, por exemplo, que os formalistas não compreenderam a importância dos gêneros, quando esses devem ser o ponto de partida da Poética, Medvedev constrói o contexto teórico-metodológico em que a proposição sobre gênero estará ancorada, contrapondo-se ao estudo do gênero entrevisto unicamente por meio dos elementos formais da língua e propondo sua compreensão a partir da totalidade da obra/enunciado. Importante observar, de

ricos exemplos do plurilinguismo real: relação entre língua, gêneros, tempo, espaço, ideologia, estratos sociais $[\ldots]$

4 Capítulo 7 da segunda parte, na edição americana; capítulo 3, da terceira parte, na espanhola; terceiro subitem da terceira parte, na edição francesa; Capítulo Terceiro da Terceira Parte, na edição brasileira.

5 A esse respeito, ver a leitura de Morson e Emerson (1990) em que, no item "Ler de baixo para cima", estão elencados os argumentos dos formalistas a respeito de gênero e a maneira como Medvedev se contrapõe a eles. 
imediato, um primeiro traço que caracteriza o conjunto dos trabalhos do Círculo sobre gênero e que está aqui destacado: sem dispensar os aspectos formais da língua eles propõem a articulação necessária com um novo ponto de vista, isto é, com a totalidade do enunciado.

Oferecendo uma fina discussão teórica e metodológica, o capítulo vai construindo definições, de forma a explicitar aspectos essenciais à compreensão de gênero do discurso, que, ao final, poderia ser resumido da seguinte maneira: O gênero emerge da totalidade concluída e solucionada do enunciado, que é $o$ ato realizado por sujeitos organizados socialmente de uma determinada maneira. Trata-se de uma totalidade temática, orientada pela realidade circundante, marcada por um tempo e um espaço. É importante destacar aqui o sentido de enunciado como todo que articula interior/ exterior, que o autor reitera em outros momentos, e que coincide com os demais trabalhos do Círculo.

Dentre as características de gênero do discurso, merece atenção a ideia de que o gênero se define a partir de uma dupla orientação na realidade. Esse aspecto reitera a ideia presente em todos os trabalhos do Círculo, ou seja, para conceber gênero é necessário considerar as circunstâncias temporais, espaciais, ideológicas que orientam o discurso e o constituem, assim como os elementos linguísticos, enunciativos, formais que possibilitam sua existência. A primeira orientação é considerada a partir da exterioridade implicada no gênero, ou seja, relacionada à vida, no que diz respeito a tempo, espaço e esfera ideológica a que o gênero se filia. Compreende-se, assim, que o enunciado como totalidade se produz num espaço e num tempo reais, podendo ser oral ou escrito, implicando a existência de um auditório de receptores, destinatários, ouvintes e/ou leitores, e de certo modo a reação dessa recepção. Estabelece-se, portanto, entre o receptor e o autor uma inter-relação, uma interação.

A segunda orientação, também voltada para a vida, se dá a partir da interioridade do gênero, relacionada a formas, estruturas e conteúdo temático do enunciado em sua totalidade, fator que lhe permite ocupar um lugar na vida cotidiana, unindo-se ou aproximando-se de uma esfera ideológica. Aqui, a reiteração da dimensão marcada por aspectos linguísticos, forma, conteúdo temático, não pode ser desvinculada de outro aspecto essencial à concepção de gênero presente no pensamento bakhtiniano: a noção de esfera ideológica que envolve e constitui a produção, circulação e recepção de um gênero, pontuando sua relação com a vida, no sentido cultural, social, etc. Medvedev dá dois exemplos da dupla orientação do gênero na realidade: o primeiro é a ode, que, situada num determinado tempo e voltada para um auditório específico, é parte de uma festividade, unida à vida política e seus atos; o segundo é a lírica litúrgica, que é parte do serviço religioso. 
Considerar gênero, enquanto enunciado em sua totalidade, com dupla orientação na realidade, significa entender que

[...] uma obra entra na vida e está em contato com os diferentes aspectos da realidade circundante mediante o processo de sua realização efetiva, como executada, ouvida, lida em determinado tempo, lugar e circunstâncias. Ela ocupa certo lugar, que é concedido pela vida, enquanto corpo sonoro real. Esse corpo está disposto entre as pessoas que estão organizadas de determinada forma. Essa orientação imediata da palavra como fato, mais exatamente como feito histórico na realidade circundante, determina toda a variedade de gêneros dramáticos, líricos e épicos. (MEDVIÉDEV, 2012, P.195).

Além dessa característica essencial é necessário destacar ao menos outra, relacionada à dimensão temática, e que está assim definida:

Cada gênero é capaz de dominar somente determinados aspectos da realidade, ele possui certos princípios de seleção, determinadas formas de visão e de compreensão dessa realidade, certos graus na extensão de sua apreensão e na profundidade de penetração nela. (MEDVIÉDEV, 2012, p.196).

A partir de minuciosa discussão, o autor esclarece, ainda, o difícil conceito de tema, de unidade temática, demonstrando que essa dimensão do gênero constitui-se com a ajuda dos elementos semânticos da língua, pois é com a ajuda da língua que dominamos o tema, mas que este transcende a língua. O que está orientado para o tema é o enunciado inteiro como atuação discursiva, a totalidade e suas formas, irredutíveis às formas linguísticas. Segundo o autor, o tema deriva do enunciado completo, enquanto ato sóciohistórico determinado, inseparável tanto da situação da enunciação quanto dos elementos linguísticos. O tema, que não pode ser confundido simplesmente com assunto, é tratado de forma detalhada, podendo ser assim resumido: (i) o conjunto dos significados dos elementos verbais da obra é um dos recursos para dominar o tema, mas não o tema em si mesmo; (ii) constitui-se com a ajuda dos elementos semânticos da língua; (iii) não é uma palavra isolada que está orientada para o tema, mas o enunciado inteiro como atuação discursiva; (iv) advém do enunciado completo/obra completa enquanto ato sócio-histórico determinado, sendo, portanto, inseparável tanto da situação da enunciação como dos elementos linguísticos; (v) não pode ser introduzido no enunciado e encerrado.

Como se pode observar, essa concepção de tema está ligada, teórica e metodologicamente, à dupla orientação do gênero na realidade: 
[...] a unidade temática da obra é inseparável de sua orientação original na realidade circundante, isto é, inseparável das circunstâncias espaciais e temporais.

Assim, entre a primeira e a segunda orientação da obra na realidade (orienta ção imediata a partir de fora e temática a partir de dentro), estabelece-se uma ligação e uma interdependência indissolúveis. Uma é determinada pela outra. A dupla orientação acaba por ser única, porém bilateral.

A unidade temática da obra e seu lugar real na vida unem-se, de forma orgânica, na unidade dos gêneros. (MEDVIÉDEV, 2012, p.197).

Considerando que "[...] cada gênero possui seus próprios meios de visão e de compreensão da realidade, que são acessíveis somente a ele" (MEDVIÉDEV, 2012, p.198), ${ }^{6}$ exemplifica com as artes plásticas para demonstrar que visão, representação e gêneros se fundem:

\begin{abstract}
Seria ingênuo considerar que, nas artes plásticas, o homem primeiro vê e depois retrata o que viu, inserindo sua visão no plano do quadro com a ajuda de determinados meios técnicos. Na verdade, a visão e a representação geralmente fundem-se. Novos meios de representação forçam-nos a ver novos aspectos da realidade, assim como estes não podem ser compreendidos e introduzidos, de modo essencial, no nosso horizonte sem os novos recursos de sua fixação. A ligação entre eles é inseparável. (MEDVIÉDEV, 2012, p.199).
\end{abstract}

É muito importante observar que todos esses aspectos dizem respeito ao gênero e suas características essenciais, e não apenas aos gêneros englobados pela poética, como se pode observar em outro exemplo dado por Medvedev: a piada que, como gênero, caracteriza-se pela capacidade de construir e contar aspectos anedóticos da vida, segundo um modo particular de organização do material. Nem o material vale por si mesmo, nem tampouco os aspectos anedóticos isolados. É necessário um enunciado anedótico, construído e contado por um sujeito, participante de uma comunidade organizada de um determinado modo, que se dirige a um determinado auditório, objetivando sua reação, estabelecendo o processo de interação, para a piada se concretizar como gênero.

Esse texto demonstra, criteriosa e detalhadamente, que gênero é o conjunto dos modos de orientação coletiva dentro da realidade, encaminhado para a conclusão de que, por meio do gênero, é possível compreender novos aspectos da realidade, ou, em outras palavras, a realidade do gênero é a realidade social de sua realização no processo da comunicação, ligados de forma estreita ao pensar.

6 Em resposta a uma pergunta da revista Novi Mir, 1970, Bakhtin (2003, p.364). afirma basicamente o mesmo: "Ao longo de séculos de sua vida, os gêneros (da literatura e do discurso) acumulam formas de visão e assimilação de determinados aspectos do mundo." 


\section{O conceito de gênero em Marxismo e filosofia da linguagem}

Raramente ocorre aos estudiosos de gênero do discurso consultar a obra Marxismo e filosofia da linguagem. Problemas fundamentais do método sociológico na ciência da linguagem, também disputada por Bakhtin eVolochinov na maioria das edições, mas não na mais recente, a francesa bilíngue (russofrancês), traduzida por Patrick Sériot e Inna Tylkowski-Ageeva (VOLOŠINOV, 2010). E menos ainda à primeira parte intitulada a "Filosofia da linguagem e sua importância para o marxismo". Mas é sobretudo nela, e de maneira específica no capítulo 2, "Relação entre a infraestrutura e as superestruturas", que a questão dos gêneros, ou formas dos enunciados em combinação com formas da comunicação verbal, está introduzida e discutida.

Dentre os interlocutores polemizados por Volochinov estão a linguística saussureana, a estilística clássica, a psicologia subjetivista e também a causalidade mecanicista da relação entre infraestrutura e superestruturas. Isso fica muito claro na discussão sobre o subjetivismo idealista e o objetivismo abstrato, além de outras partes em que a psicologia praticada na Rússia daquele momento é contestada. Para trabalhar os problemas do método sociológico na ciência da linguagem, o autor delimita o problema: "[...] saber como a realidade determina o signo e como o signo reflete e refrata a realidade em transformação." (BAKHTIN; VOLOCHINOV, 1997, p.41, grifo do autor). Depois de retomar a palavra como signo ideológico, a interação verbal, o processo real de comunicação, a psicologia do corpo social / a ideologia do cotidiano, discute o que os atos de fala, as diferentes formas de discurso que ocorrem na comunicação socioideológica de cada época e de cada grupo social. ${ }^{7}$ Insiste na necessidade da classificação dessas formas, da criação de uma tipologia apoiada na classificação das formas da comunicação verbal e relacionada com o enunciado e o diálogo. Afirmando que a psicologia do corpo social é inteiramente exteriorizada na palavra, no gesto, no ato, no material, principalmente no verbal, articula relações de produção, estrutura sociopolítica, contatos verbais, formas e meios de comunicação, chegando aos atos de fala:

As relações de produção e a estrutura sociopolítica que delas diretamente deriva determina todos os contatos verbais possíveis entre indivíduos, todas as formas e os meios de comunicação verbal: no trabalho, na vida política, na criação ideológica. Por sua vez, das condições, formas e tipos da comunicação verbal derivam tanto os temas como as formas dos atos de fala. (BAKHTIN; VOLOCHINOV, 1997, p.42).

Na tradução para o espanhol: "Cada época y cada grupo social tiene su repertorio de las formas discursivas de la comunicación ideológica real. A cada grupo de formas homogêneas, es decir, a cada gênero discursivo concreto, le corresponde su conjunto de temas." (VOLOSHINOV, 2009, p.43, grifo nosso). 
Ao colocar a psicologia do corpo social como o meio ambiente inicial dos atos de fala de toda espécie, afirma que ela se manifesta nos diversos aspectos da "enunciação", sob forma de diferentes modos de discurso:

A psicologia do corpo social é justamente o meio ambiente inicial dos atos de fala de toda espécie, e é neste elemento que se acham submersas todas as formas e aspectos da criação ideológica ininterrupta: as conversas de corredor, as trocas de opinião no teatro e, no concerto, nas diferentes reuniões sociais, as trocas puramente fortuitas, o modo de reação verbal face às realidades da vida e aos acontecimentos do dia-a-dia, o discurso interior e a consciência auto-referente, a regulamentação social, etc. A psicologia do corpo social se manifesta essencialmente nos mais diversos aspectos da "enunciação" sob a forma de diferentes modos de discurso, sejam eles interiores ou exteriores [...] Todas estas manifestações verbais estão, por certo, ligadas aos demais tipos de manifestação e de interação de natureza semiótica, à mímica, à linguagem gestual, aos gestos condicionados, etc. (BAKHTIN; VOLOCHINOV, 1997, p.42, grifo do autor).

Considerando que os atos de fala - enunciação sob diferentes modos de discurso - são formas de interação verbal diretamente vinculadas a uma situação social e que, por isso, "[...] reagem de maneira muito sensível a todas as flutuações da atmosfera social" (BAKHTIN; VOLOCHINOV, 1997, p.42), afirma que a psicologia do corpo social/ideologia do cotidiano deve ser estudada de duas maneiras, sendo uma delas a que diz respeito aos conteúdos dos temas atualizados num dado tempo e num dado espaço e, a outra, "[...] do ponto de vista dos tipos e formas de discurso através dos quais esses temas tomam forma, são comentados, se realizam, são experimentados, são pensados, etc." (BAKHTIN; VOLOCHINOV, 1997, p.42).

Essa postura está muito próxima da de Medvedev, no texto "Os elementos da construção artística", e de muitos aspectos do que Bakhtin desenvolve em "Gêneros do discurso". Volochinov afirma, por exemplo, que a cada grupo de formas similares (atos de fala), isto é, a cada gênero de discurso, utilizado na vida cotidiana, corresponde um grupo de temas e que, entre a forma da troca verbal e seu tema ou a forma do enunciado e seu tema, existe uma unidade orgânica indissolúvel. Explicita, ainda, aspecto que de certa maneira aponta para a dupla orientação do gênero para a realidade, apresentada por Medvedev, que essa concepção, e o trabalho que dele deriva em relação à evolução social do signo, está submetida a exigências metodológicas fundamentais para a ciência das ideologias:

a) Não separar a ideologia da realidade material do signo (colocando-a no campo da consciência ou de outros domínios fugidios e indefiníveis); 
b) Não separar o signo das formas concretas da comunicação social (entendendo-se que o signo faz parte de um sistema de comunicação social organizada e que não tem existência fora desse sistema, a não ser como objeto físico);

c) Não dissociar a comunicação e suas formas de sua base material (BAKHTIN; VOLOCHINOV, 1997, p.44).

De olho no signo, em sua constituição semiótico-ideológica, nesse capítulo Volochinov aponta para a necessidade de elaboração de uma tipologia dos atos de fala ou das intervenções verbais, conforme prefere Patrick Sériot, estabelecendo uma relação com as reflexões sobre gênero encontradas em Medvedev e vários trabalhos de Bakhtin:

Mais tarde, em conexão com o problema da enunciação e do diálogo, abordaremos também o problema dos gêneros linguísticos. A este respeito faremos simplesmente a seguinte observação: cada época e cada grupo social têm seu repertório de formas de discurso na comunicação sócio-ideológica. A cada grupo de formas pertencentes ao mesmo gênero, isto é, a cada forma de discurso social, corresponde um grupo de temas. Entre as formas de comunicação (por exemplo, relações entre colaboradores num contexto puramente técnico), a forma de enunciação ("respostas curtas" na "linguagem de negócios") e enfim o tema, existe uma unidade orgânica que nada poderia destruir. Eis porque a classificação das formas de enunciação deve apoiar-se sobre uma classificação das formas da comunicação verbal. (BAKHTIN; VOLOCHINOV, 1997, p.43, grifo nosso).

Para concluir as indicações de que Volochinov também apresenta aspectos concretos para a concepção de gênero no conjunto dos trabalhos do Círculo, formulando hipóteses fortes e coerentes, observa-se que a riqueza desse capítulo, aqui apenas resumida, é retomada na segunda parte de Marxismo e filosofia da linguagem, capítulo 6, em que Volochinov trata da interação verbal, que na tradução em espanhol aparece como interación discursiva. Nesse capítulo, novamente, encontram-se importantes observações a respeito das "categorias de atos de fala na vida e na criação ideológica", em estreita ligação com aquilo que Volochinov entende como a verdadeira substância da língua, a interação verbal, e com as próprias regras metodológicas de seu estudo.

Mantendo o tom polêmico da obra e refutando o subjetivismo idealista, Volochinov (2009, p.121) demonstra que a "enunciação é de natureza social"; que toda enunciação é determinada pela situação social mais imediata e o meio social mais amplo; que mesmo o discurso interior de cada indivíduo - adaptado e organizado de acordo com as possibilidades de expressão do meio social em que vive - tem um auditório próprio bem estabelecido; que o "...] centro organizador 
de toda enunciação, de toda expressão, não é interior, mas exterior: está situado no meio social que envolve o indivíduo."

É justamente dessa ligação entre a língua e o curso da comunicação verbal concreta, social e historicamente situada, fora da qual não se pode compreendê-la, que decorre a ordem metodológica para seu estudo, no qual o reconhecimento do gênero tem lugar de destaque: ${ }^{8}$

1. As formas e os tipos de interação verbal em ligação com as condições concretas em que se realiza.

2. As formas das distintas enunciações, dos atos de fala isolados, em ligação estreita com a interação de que constituem os elementos, isto é, as categorias de atos de fala na vida e na criação ideológica que se prestam a uma determinação pela interação verbal

3. A partir daí, exame das formas da língua na sua interpretação linguística habitual. (VOLOCHINOV, 2009, p.124, grifo do autor).

Dentre outros fatores ligados ao conceito de gênero, Volochinov (2009, p.125) trata, ainda, nesse capítulo: dos pontos de contato de uma determinada enunciação com o "meio extraverbal e o verbal"- o interior e o exterior do enunciado, questão também tratada por Medvedev; da importância do auditório e das formas composicionais: "Toda situação inscrita duravelmente nos costumes possui um auditório organizado de uma certa maneira e consequentemente um certo repertório de pequenas fórmulas correntes." (VOLOCHINOV, 2009, p.126). O capítulo seguinte, "Tema e significação na língua", contribui para esclarecer colocações feitas por Medvedev e Bakhtin a respeito das ligações existentes entre conteúdo temático e gênero.

Para reforçar a ideia de que nenhum conceito do Círculo pode ser compreendido isoladamente - nem gênero, nem dialogismo, relações dialógicas, tema, língua, linguagem [...] -, invoca-se finalmente o texto "A construção do enunciado/enunciação", de 1930, em que Volochinov, voltando a tratar da interação, do discurso monológico e do discurso dialógico, da dialogicidade da linguagem interior, da orientação social do enunciado/enunciação, da parte extraverbal - subentendida - do enunciado/enunciação, da situação e da forma do enunciado/enunciação: entonação, escolha e disposição das palavras, da

\footnotetext{
Na tradução para o espanhol, esta questão se coloca com mais clareza: "El lenguaje vive y se genera históricamente en la comunicación discursiva concreta, y no en un sistema linguístico abstracto de formas, ni tampoco en la psique individual de los hablantes. Por consiguiente, un orden metodológicamente fundado del estudio del lenguaje debe ser el siguiente: 1) formas y tipos de interacción discursiva en relación con sus condiciones concretas; 2) formas de enunciados concretos, de algunas actuaciones discursivas en estrecha relación con la interacción cuyos elementos son estos enunciados, esto es, los géneros de las actuaciones discursivas, determinados por la interacción discursiva, en la vida y la creación ideológica; 3) a partir de ahí, una revisión de las formas del lenguaje tomadas en su versión linguística habitual" (VOLÓSHINOV, 2009, p.153-154).
} 
estilística do enunciado/enunciação na vida cotidiana, retoma a questão do gênero e afirma:

Cada um dos tipos de intercâmbio comunicativo [...] organiza, constrói e completa, à sua maneira, a forma gramatical e estilística do enunciado/ enunciação, sua estrutura tipo, que na sequência chamaremos de gênero (BAJTÍ́N; VOLOCHINOV, 1993, p.248, tradução nossa).

\section{Gênero do discurso, leitura, compreensão e produção de textos: um gênero sozinho não salva o ensino}

Conforme proposta inicial, este item está dedicado à leitura de gêneros. Como se verá, as dimensões teóricas e metodológicas, explicitadas acima, acarretam consequências para a compreensão de textos e discursos, atestando, sobretudo, a produtividade da noção de gênero tal como concebida pelo Círculo. Uma página de jornal, representante de uma esfera de atividade humana - o jornalismo, e mais amplamente a mídia - que tem tido grande penetração na escola, foi selecionada para análise.

Examinada como totalidade, a figura acima revela o diálogo da mídia com o discurso jurídico, mais especificamente o processo judicial nº.17.901/97, e em especial a sentença de primeira instância, de 09 de agosto de 1997, que modifica a tipificação de um delito, aquele que julgou quatro rapazes de classe média acusados pelo assassinato de um índio pataxó em Brasília, em 20 de abril de 1997. O Ministério Público havia requerido a classificação do crime como "homicídio doloso triplamente qualificado" e a sentença, cujo posicionamento é questionado na página, acata a denúncia, mas considera a ocorrência do crime de "lesões corporais seguidas de morte."

Há vários gêneros jornalísticos na página; porém, para a apreensão de alguns dos sentidos em jogo, é necessário compreender suas condições concretas de vida, suas interdependências e relações, suas posições dialógicas e valorativas, isto é, a forma arquitetônica que governa a construção da massa verbal - ou verbo-visual, neste caso - e, consequentemente, constrói seu plano, a forma composicional e o estilo. Para tanto, é preciso lembrar que a mídia constitui-se do conjunto de organismos especializados que têm o dever de informação a serviço da democracia, em benefício do cidadão - o destinatário dos veículos de comunicação. Mas, ao mesmo tempo, define-se, também, por uma lógica comercial de empresa, numa economia de tipo liberal. Isso lhe 
Figura 1 - Uma página de jornal.

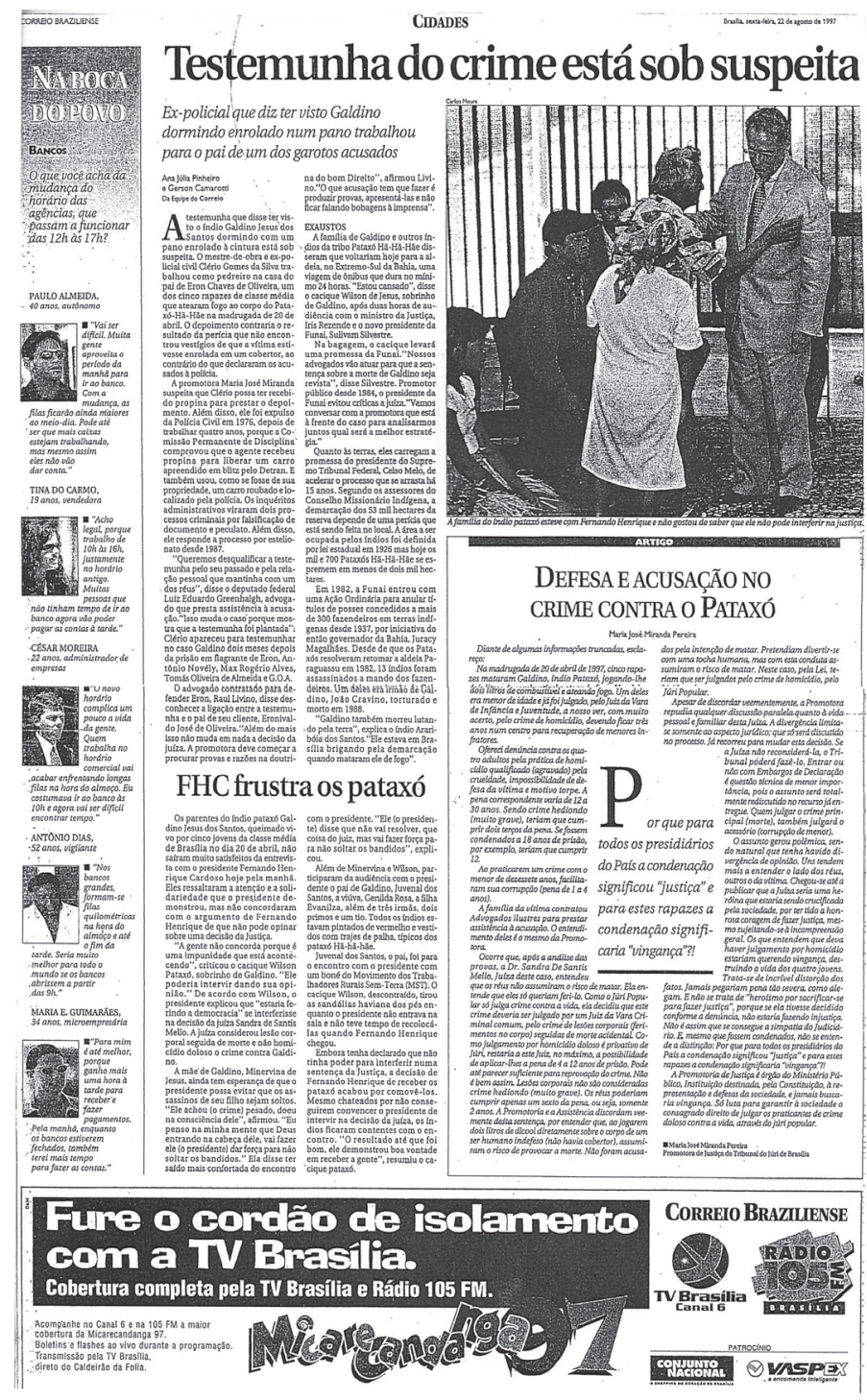

Fonte: CORREIO BRAZILIENSE (22 ago. 1997, p.05).

dá uma finalidade ambígua, no dizer de Charaudeau (2009), na medida em que se preocupa com a captação e sedução do maior número de leitores, estando sujeita a regras próprias - as coerções da esfera de atividade jornalística. Por meio das notícias veiculadas, o jornal pretende sempre a construção do efeito de sentido de verdade; para isso, a busca da credibilidade pelo veículo midiático é uma de suas primeiras coerções (CHARAUDEAU, 2009, p.49). 
O jornal Correio Braziliense, vinculado à empresa Diários Associados, é o jornal de maior circulação no Centro-Oeste e o mais influente no Distrito Federal. Criado no século XIX, 1808, ${ }^{9}$ no Rio de Janeiro, foi relançado por ocasião da inauguração de Brasília, em 21 de abril de 1960. Sob o ponto de vista diacrônico, tal aspecto tradicional e histórico também é fator constituinte de sua credibilidade. Ora, os gêneros se definem a partir de uma dupla orientação na realidade; portanto, essas condições concretas em que se realizaram os enunciados jornalísticos constantes dessa página - relacionadas à vida, orientaram os leitores do exterior. Mas não apenas isso: no que diz respeito a tempo e espaço que os gêneros dessa página compartilham, vale lembrar que é momento de grande agitação política e midiática, com debates a respeito da emenda de reeleição para presidente, da compra de votos para beneficiar sua aprovação, do crescimento do movimento dos sem-terra e das reivindicações indígenas referentes a terras, ocorridas particularmente na data anterior ao delito, 19 de abril, em que se comemora o dia do índio. São fatos que ocuparam grande espaço na mídia, e também no processo, pois o discurso jurídico utiliza-se da mídia - "porta-voz da opinião pública" -, como argumento do processo judicial (PISTORI, 2008). Exterior às enunciações concretas, mas explicitador do relevo de que se constituem na mídia, o fato é que o caso granjeou destaque midiático nacional e internacional por motivos vários: aspectos de privilégios envolvidos - a origem sócio-econômica dos criminosos em contraste com os de exclusão social da vítima - um índio, que tem proteção constitucional especial; a crueldade inusitada do crime; e o "motivo torpe" alegado: queriam se divertir..., dentre outros.

Essa página, um enunciado concreto, é constituída pelo visual e o verbal reunidos num projeto gráfico único (PISTORI, 2011). Com data posterior à sentença de qualificação, mostra acontecimentos que se seguiram a ela, sobretudo opondose a ela. Compõem-se de: notícia da manchete - "Testemunha do crime está sob suspeita"; foto da família do índio pataxó com o presidente; notícia logo abaixo "FHC frustra os pataxós"; artigo de opinião - "Defesa e acusação no crime contra o Pataxó", de Maria José Miranda Pereira; enquete - "Na boca do povo", a respeito da mudança de horário de funcionamento dos bancos, destoando tematicamente da página, mas acrescentando-lhe certa leveza do cotidiano e possibilitando a participação efetiva do leitor no jornal; e, ainda, publicidade do grupo proprietário do jornal, os Diários Associados. O jornal se posiciona a favor da posição da Promotoria, valorizando a hierarquização do direito à vida, um direito amplo, para todos, como superior ao direito de defesa dos acusados. Defende que o delito seja tipificado tal como requerido na denúncia - homicídio doloso triplamente qualificado e, consequentemente, punição maior aos réus.

9 Conforme informações no site dos Diários Associados, a marca Correio Braziliense simboliza o início da imprensa escrita no Brasil, há 200 anos. Editado em Londres por Hipólito José da Costa, circulou no Brasil e em Portugal entre 1808 e 1822. 
A segunda orientação genérica, do interior dos enunciados, relaciona-se às formas, estruturas e conteúdo temático em sua totalidade, aproximando-os de uma esfera ideológica própria. Assim, é possível observar que, no discurso jornalístico, alguns gêneros sofrem maiores coerções internas, atendendo a recomendações de manuais de redação da imprensa ou a textos de formação profissional. Por exemplo, ensina-se ao jornalista (FOLHA DE SÃO PAULO, 2010, p.26-27) a necessidade de apurar as diferentes versões de um acontecimento, na conferência da "exatidão dos fatos" ao noticiá-lo. Nas palavras de Charaudeau (2009, p.51): "Pessoas acusadas de deslize, por mais justificadas que pareçam as acusações, devem ser imediatamente ouvidas. A notícia que acusa deve assegurar também a defesa, a fim de que fiquem claras as versões para quem acompanha os fatos."

Assim, atendendo às coerções genéricas de apuração dos fatos de modo responsável e transparente, já na primeira notícia da página "Testemunha do crime está sob suspeita", um dos advogados da defesa é ouvido. No próprio olho da notícia, entretanto, já se observa a adesão do jornal à posição de suspeita em relação à testemunha do crime: "Ex-policial que diz ter visto Galdino dormindo enrolado num pano trabalhou para o pai de um dos garotos acusados." (CORREIO BRAZILIENSE, 1997, p.05, grifo nosso). Essa suspeita é detalhada na primeira coluna da notícia, por meio de uma enumeração de fatos: (1) a testemunha trabalhou como pedreiro na casa de um dos acusados; (2) seu depoimento contraria o resultado da perícia; (3) ele foi expulso da Polícia Civil em 1978 por ter recebido propina para liberar um carro; (4) está envolvido em dois processos criminais de falsificação e peculato; (5) responde a processo por estelionato; (6) aparece para testemunhar dois meses depois da prisão em flagrante dos réus. Em seguida, aparece em discurso direto a fala do assistente do Ministério Público, afirmando realmente a intenção de desqualificar a testemunha: "Queremos desqualificar a testemunha pelo seu passado e pela relação pessoal que mantinha com um dos réus. Isso muda o caso porque mostra que a testemunha foi plantada."

Já a posição do outro lado, o advogado de defesa, ocupa somente o último dos quatro parágrafos da notícia: ele "diz desconhecer a ligação entre a testemunha e o pai de seu cliente...". E acrescenta, também com o objetivo de desqualificação da parte adversa: "Além do mais isso não muda em nada a decisão da juíza. A promotora deve começar a procurar provas e razões na doutrina do bom Direito... O que a acusação tem que fazer é produzir provas, apresentá-las e não ficar falando bobagens à imprensa" (CORREIO BRAZILIENSE, 1997, p.05, grifo nosso). Isto é, o exemplo mostra que o jornal atende apenas formalmente às coerções genéricas, dando espaço mínimo ao contraditório.

Alguns aspectos do projeto visual da página merecem atenção. A foto no alto, à direita, parece ilustrar a matéria que está mais abaixo, à esquerda. Conforme ensina o Manual da redação (FOLHA DE SÃO PAULO, 2010), o espaço ocupado por 
uma notícia ou foto tem o objetivo de orientar o leitor em relação à importância dos temas, e ainda prevê a ordem progressiva de interesse. Pela foto, percebe-se que, aos olhos do jornal, a notícia a respeito da testemunha do crime é tão importante quanto a visita feita ao Presidente Fernando Henrique Cardoso pelos parentes do índio pataxó assassinado. Aliás, talvez mais importante, porque mereceu a foto.

Uma fotografia - escreve Henri Cartier-Bresson [em Cadernos de Jornalismo e Comunicação, nov.-dez. 1970] - é o reconhecimento simultâneo, numa fração de segundo, da significação de um fato e de uma organização rigorosa das formas percebidas visualmente que exprimem esse fato. (CARTIER-BRESSON apud BAHIA, 2009, p.143).

A verticalidade da figura do presidente FHC, também à direita, domina a foto, sobrepondo-se ao grupo e dando destaque à posição político-institucional de não interferência entre os poderes, pois isso "estaria ferindo a democracia", citada no artigo abaixo. Em oposição a ela, expressando simpatia pelos índios, sua cabeça, levemente inclinada para baixo e para direita, busca demonstrar atenção e solidariedade em relação ao grupo. A legenda antecipa a notícia, afirmando que os índios "não concordaram" com a posição do presidente: "A família do índio pataxó esteve com Fernando Henrique e não gostou de saber que ele não pode interferir na justiça" (foto e legenda reunidos num todo indissolúvel). Em discurso indireto, o enunciador recriou à sua maneira a enunciação, dando-lhe uma orientação particular - o ponto de vista das vítimas (BAKHTIN; VOLOCHINOV, 1997, p.158, grifo nosso). A legenda - uma transmissão analítica do discurso dos índios, reforça o posicionamento pró-acusação da página, reiterado na matéria. A posição do presidente está no título da notícia abaixo - "FHC frustra os pataxó", uma avaliação do conteúdo da audiência concedida por FHC aos familiares e chefes da tribo, orientada pela visão dos índios. Nela, o destaque é para as posições da tribo, cujo posicionamento crítico e insatisfeito orienta os discursos citados, avaliando-lhes o conteúdo. Eles são apresentados ora em discurso direto, na busca de conservação de sua autenticidade, ora em indireto, conforme os exemplos:

A gente não concorda porque é uma impunidade que está acontecendo", criticou o cacique Wilson Pataxó, sobrinho de Galdino [...]

A mãe de Galdino, Minervina de Jesus, ainda tem esperança de que o presidente possa evitar que os assassinos de seu filho sejam soltos. Ele achou (o crime) pesado, doeu na consciência dele", afirmou (CORREIO BRAZILIENSE, 1997, p.05, grifo nosso).

Quanto ao artigo de opinião, abaixo da foto, chama a atenção, em primeiro lugar, sua autoria: é assinado pela representante do Ministério Público responsável pela acusação no processo, Maria José Miranda Pereira; e, em seguida, não ser apresentado como "opinião". Na realidade, inicia-se como 
um depoimento, com a marca enunciativa da primeira pessoa do singular, e é assertivo desde o título, em forma nominal, obedecendo às orientações do gênero: "Defesa e acusação no crime contra o Pataxó." Isso lhe confere uma aura de imparcialidade diante dos fatos: o locutor se propõe a apresentá-los não apenas do ponto de vista da acusação, que seria próprio da promotoria, mas também da defesa. No entanto, não é isso o que ocorre. No primeiro parágrafo, com o intuito de fazer crer verdadeiro o modo como vê os fatos e o processo, o enunciador destaca a função de "esclarecimento" de seu texto: "Diante de algumas informações truncadas, esclareço". O apreciativo pejorativo - "truncadas" - enfatiza o dever do enunciador de complementá-las, corrigi-las. No segundo parágrafo, ao tratar da condenação por homicídio do menor de idade envolvido no delito, o enunciador oscila no tratamento e utiliza o plural para concordar com aquela decisão: "a nosso ver, com muito acerto" - é o nós que teria atrás de si a comunidade jurídica. O artigo segue em primeira pessoa: "Ofereci denúncia contra os quatro adultos [...]" Mas a primeira pessoa não ocorre mais no texto, e sim a neutralização pela terceira pessoa (FIORIN, 2001, p.85-86), concorrendo para o efeito de sentido de verdade e imparcialidade perante os fatos: no sexto parágrafo, "A Promotoria e a Assistência discordam veemente[mente] desta sentença [...]"; no oitavo, "a Promotora repudia qualquer discussão paralela quanto à vida pessoal e familiar desta Juíza. A divergência limita-se somente ao aspecto jurídico que só será discutido no processo"; no último, "A Promotoria de Justiça é órgão do Ministério Público, instituição destinada, pela Constituição, à representação e defesas da sociedade, e jamais buscaria vingança. Só luta para garantir à sociedade o consagrado direito de julgar os praticantes de crime doloso contra a vida, através do júri popular".

Conforme observado, ainda que se inicie como um depoimento, o "artigo" busca impor uma visão de mundo de ordem explicativa, não se contentando em mostrar o que foi o delito, "[...] procura revelar o que não se vê, o que é latente e constitui o motor (causas, motivos e intenções) do processo [...]" (CHARAUDEAU, 2009, p.176), naturalizando o jurídico como anterior ao cotidiano, mais próximo do discurso das mídias. As perspectivas genéricas em conflito demonstram que o texto não consegue se desprender do ponto de vista da acusação: (i) quer na seleção das palavras, revelando a articulação existente entre língua, gêneros, estilo e autoria - ao utilizar os termos pertencentes ao mundo jurídico, o enunciador rompe a continuidade enunciativa e oferece, entre parênteses, como uma glosa, o significado cotidiano, reiterável, com o intuito de explicar as próprias palavras. Por exemplo: "Ofereci denúncia contra os quatro adultos pela prática de homicídio qualificado (agravado) pela crueldade, impossibilidade defesa da vítima e motivo torpe. [...] Sendo crime hediondo (muito grave), teriam que cumprir dois terços da pena." ( $\left.3^{\circ} \S\right)$; (ii) quer na repetição dos argumentos apresentados no processo, conforme podemos comparar neste parágrafo, entre outros: 
Chegou-se até a publicar que a Juíza seria uma heroína que estaria sendo crucificada pela sociedade, por ter tido a honrosa coragem de fazer justiça, mesmo sujeitando-se à incompreensão geral. Os que entendem que deva haver julgamento por homicídio estariam querendo vingança, destruindo a vida dos quatro jovens. (PEREIRA, 1997, p.05, grifo nosso).

Por que para todos os presidiários do país a condenação significou "justiça" e para esses rapazes a condenação significaria "vingança"? (Olho do artigo, Correio Braziliense)

Alguns simpatizantes da causa defensiva proclamaram que a sentença demonstrou e significou "coragem de enfrentar toda a sociedade nacional e internacional para fazer justiça”. Este raciocínio traz ínsita uma inverdade incontestável: a de que pronunciar os réus significaria injustiça. (BRASIL, 1997, p.639; grifo do autor).

Em conflito com o outro, o enunciador, ao utilizar ironicamente as palavras dos "simpatizantes da causa defensiva" que se expressaram na mídia a respeito da "coragem" da juíza ao desqualificar o delito e não pronunciar os réus por homicídio triplamente qualificado, força a percepção da distância existente entre os diferentes posicionamentos avaliativos: o raciocínio do outro contém uma "inverdade incontestável". Num raciocínio pelo absurdo, o enunciador afirma que admitir tal "coragem" significaria considerar "injustiça" o pronunciamento dos réus. Fiel ao gênero "acusação", tanto o parágrafo publicado na mídia como o do processo exemplificam como a Promotoria vê e conceitua a realidade do crime em julgamento e expressa a relação valorativa do locutor com o objeto do discurso.

A página, na breve análise dos textos feita aqui, não é exemplo de apresentação imparcial do fato: dá pouco espaço ao outro lado. O tema emerge da totalidade dos enunciados da página - o posicionamento do jornal a favor da tese da promotoria, mas orienta-se pela realidade circundante, articulando exterior e interior nos diferentes enunciados da página. Na busca da interação com o maior número de leitores, personifica um sujeito histórica e socialmente situado que se dirige preferencialmente a um destinatário que concebe a punição do delito como a punição do privilégio e dos privilegiados.

"Qualquer enunciação, por mais significativa e completa que seja, constitui apenas uma fração de uma corrente de comunicação verbal ininterrupta [...]" (BAKHTIN; VOLOCHINOV, 1997, p.123). É bem isso que pode ser observado nessa página: os enunciados todos dialogam entre si e com a realidade exterior em transformação, refletindo-a e refratando-a. Cada um dos gêneros - notícia, foto com legenda, artigo de opinião - ilumina a realidade à sua maneira; por outro lado, a realidade traz luz sobre os gêneros, motivando sua compreensão na totalidade da enunciação concreta - a página do jornal, em seu diálogo verbal e extraverbal com o mundo, expressão de valores e tensões que regem nossa cultura e sociedade. 


\section{Considerações finais}

Para chegar a algumas considerações teóricas e metodológicas a respeito de gênero do discurso no conjunto do pensamento do Círculo, este artigo destacou trabalhos seminais e pouco conhecidos no que se refere a gêneros e, a partir deles, procurou praticar essa perspectiva na leitura de uma página de jornal. Essa leitura, de fato, só se completa com a leitura do jornal como um todo e dos acontecimentos com os quais a página dialoga. Nesse percurso, reafirma-se que os trabalhos de Bakhtin se harmonizam com os demais, de assinatura disputada, aqui apresentados. De um lado, o que Volochinov identificou como a necessidade de classificação de diferentes formas de discurso que ocorrem na comunicação socioideológica de cada época e de cada grupo social e que "Os gêneros do discurso" procuram dar conta, sem fechar-se numa tipologia textual. De outro, no que se refere aos trabalhos voltados para o material, a forma e o conteúdo, para Dostoiévski e para a teoria do romance, realiza-se o que Medvedev afirmou sobre a dupla orientação do gênero na realidade, citando explicitamente o gênero romance: criar a partir de uma maneira de ver e compreender a vida, material para o romance; mostrando novas relações, mais profundas, mais amplas, a lógica interna de uma época: familiar, social, psicológica, estabelecendo nexo com os modos de expressá-la, possibilitando sua expressão genérica.

Nos trabalhos aqui evocados, o objeto para a reflexão sobre os gêneros do discurso é o enunciado como totalidade, que se produz em espaço e tempo reais, implicando auditório, recepção, dupla orientação na realidade. Sem essa compreensão, corre-se o risco de deixar de lado a interioridade, a organização do material, aí incluídos os elementos linguísticos, ou a exterioridade constitutiva, relacionada, por exemplo, às esferas ideológicas. E, então, a redução a estilo, forma de composição e tema, pode significar o abandono da totalidade do enunciado, de sua dupla orientação, do tema. Não é demais repetir que o Círculo, sem dispensar os aspectos formais da língua, propõe a articulação necessária com um novo ponto de vista, isto é, a totalidade do enunciado, afirmando que cada gênero possui determinados princípios de seleção, determinadas formas de visão e concepção da realidade, determinados graus na capacidade de abarcar e na profundidade de penetração nela, que o tema deriva do enunciado completo, enquanto ato sócio-histórico determinado, inseparável tanto da situação da enunciação quanto dos elementos linguísticos.

O conjunto das obras do Círculo aponta para a ideia de que os gêneros governam os discursos do dia a dia, interiores e exteriores, na medida em que os enunciados, os textos, são formulados segundo princípios genéricos. São, portanto, formas de pensar, constituindo um modo específico de visualizar e representar 
uma dada realidade, não se reduzindo a uma coleção de dispositivos nem a um modo de combinar elementos linguísticos.

Das leituras feitas neste artigo, é possível deduzir que o conceito de gênero do discurso, segundo a perspectiva do Círculo, deve ser considerado levando-se em conta que: (i) várias obras do Círculo delineiam caminhos teóricos metodológicos; (ii) não se limita às produções literárias, dizendo respeito, também, à linguagem cotidiana em sua ampla variedade; (iii) a variedade de experiências individuais e coletivas, vivenciadas numa sociedade, num tempo, numa cultura, congrega a multiplicidade de gêneros e suas mudanças; (iv) não se limita a textos ou estruturas, embora os considere, mas implica o dialogismo e a maneira de entender e enfrentar a vida; (v) para sua compreensão é necessário observar a dupla orientação para vida, incluída na materialidade que o constitui e que aponta para fora, para a vida que o motivou e que é por ele refletida e refratada; (vi) considera a tradição em que um gênero se insere, explicitando que o gênero se liga a uma tradição genérica, que precisa ser identificada e compreendida, implicando estudos diacrônicos e sincrônicos; (vii) articula o conceito de gênero ao de discurso e/ou relações dialógicas; (viii) diferencia forma composicional e forma arquitetônica; (ix) sua descrição, análise e compreensão não pode ser limitada a forma de composição, conteúdo temático e estilo.

BRAIT, B.; PISTORI, M. H. C. Productivity of the notion of genre in bakhtin and the circle. Alfa, São Paulo, v.56, n.2, p.371-401, 2012.

- ABSTRACT: In Brazil, the concept of genre is being largely used - even in official documents and pedagogical materials. Taking into consideration how wide the theoreticalpractical framework known as genre has become, this paper addresses everyone who, in their teaching experiences and research, faces this reality and is willing to critically and constructively discuss the contemporary nuances of this concept as well as their consequences to academic, educational, or editorial institutions. To participate in this discussion, it is required to recognize that the concept of genre, in its multiple affiliations, involves different theoretical and methodological dimensions which consequences to the understanding of texts and discourses should not be ignored. Among the existing reflections on genre, we find the one developed by Bakhtin/Volochinov/Medvedev. Despite the fact that the essay "Speech genres" is the only widespread text being used in documents and research, it is not the only one to address the issue. Other works by the Circle contribute to the notion of genre based upon the idea that language is materialized in concrete utterances, articulating the "interior" and the "exterior" and making the notion of a historically and socially situated subject possible. This concept will be hereby presented both theoretically and practically.

- KEYWORDS: Speech genre. Bakhtin and the circle. Concrete utterance. Text. Discourse. Dialogic discourse analysis. Teaching. 


\section{REFERÊNCIAS}

BAHIA, B. J. As técnicas do jornalismo. 5.ed. Rio de Janeiro: Mauad X, 2009. v.2.

BAJTIN, M.; MEDVEDEV, P. N. Los elementos de la construcción artística. In: . El método formal en los estúdios literarios: introducción crítica a una poética sociológica. Versión española de Tatiana Bubnova. Madrid:Alianza, 1994. p.207-224.

BAKHTIN, M. M. Para uma filosofia do ato responsável. Tradução de Valdemir Miotello e Carlos Alberto Faraco. São Carlos: Pedro e João, 2010.

Problemas da poética de Dostoiévski. 4.ed. Tradução de Paulo Bezerra. São Paulo: Forense-Universitária, 2008.

. Os gêneros do discurso. In: . Estética da criação verbal. Tradução de P. Bezerra. São Paulo: Martins Fontes, 2003a. p.261- 306.

Apontamentos de 1970-1971. In: . Estética da criação verbal. Tradução de P. Bezerra. 4.ed. São Paulo: Martins Fontes, 2003b. p.367-392.

. Arte e responsabilidade. In: Estética da criação verbal. Tradução de P. Bezerra. 4.ed. São Paulo: Martins Fontes, 2003c. p. 113-114.

O autor e a personagem na atividade estética. In: Estética da criação verbal. Tradução de P. Bezerra. 4.ed. São Paulo: Martins Fontes, 2003d. p.03-192.

. The problem of content, material, and form in verbal art. In: HOLQUIST, M.; LIAPUNOV, V. (Ed.). Art and answerability: early philosophical essays by M. M. Bakhtin. Austin: University of Texas Press, 1990. p.257-325.

BAKHTIN, M. M. O problema do conteúdo, do material e da forma na criação literária. In: Questões de literatura e de estética: a teoria do romance. Tradução de Aurora Fornoni Bernardini et al. São Paulo: Ed. da UNESP, 1988a. p.13-70.

. O discurso no romance. In: Questões de literatura e de estética: a teoria do romance. Tradução de Aurora Fornoni Bernardini et al. São Paulo: Ed. da UNESP, 1988b. p.71-210.

BAKHTIN, M. M.; VOLOCHINOV, V. N. Relações entre a infraestrutura e as superestruturas e a interação verbal. In: . Marxismo e filosofia da linguagem: problemas fundamentais do método sociológico na ciência da linguagem. Tradução de Michel Laud e Yara F. Vieira. 8.ed. São Paulo: HUCITEC, 1997. p.39127. 
BRASIL. Processo no 17.901/97. Razões de irresignação do Ministério Público. Brasília, p.639, 1997.

CHARAUDEAU, P. Discurso das mídias. São Paulo: Contexto, 2009.

CORREIO BRAZILIENSE. Brasília: Diários Associados, 22 ago. 1997.

FARACO, C. A. Linguagem \& diálogo: as ideias linguísticas do Círculo de Bakhtin. São Paulo: Parábola, 2009a.

. O problema do conteúdo, do material e da forma na arte verbal. In: BRAIT, B. (Org.). Bakhtin, dialogismo e polifonia. São Paulo: Contexto, 2009b. p.95-111.

FIORIN, J. L. As astúcias da enunciação: as categorias de pessoa, espaço e tempo. 2.ed. São Paulo: Ática, 2001.

FOLHA DE S. PAULO. Manual da redação. São Paulo: Publifolha, 2010.

MACHADO, I. Gêneros discursivos. In: BRAIT, B. (Org.). Bakhtin: conceitos-chave. São Paulo: Contexto, 2005. p.151-166.

MEDVIÉDEV, P. N. O método formal nos estudos literários: introdução crítica a uma poética sociológica. Tradução de Sheila Camargo Grillo e Ekaterina Vólkova Américo. São Paulo: Contexto, 2012.

MEDVEDEV, P. Cercle de Bakhtine. La methode formelle en littérature:introduction à une poétique sociologique. Édition critique et traduction de BénédicteVauthier et Roger Comtet. Posface de Youri Medvedev. Toulouse: Presses Universitaires du Mirail, 2008. p.273-292.

MORSON, G. S.; EMERSON, C. Teoria dos gêneros. In: MORSON, G. S.; EMERSON, C. BAKHTIN, M. Criação de uma prosaística. Tradução de Antonio de P. Danesi. São Paulo: EDUSP, 2008. p.287- 322.

Mikhail Bakhtin: creation of a prosaics. California: Stanford University Press, 1990.

PEREIRA, M. J. M. Defesa e acusação no crime contra o Pataxó. Correio Braziliense, Brasília, p.05, 22 ago. 1997.

PISTORI, M. H. C. Persuasão e eficácia discursiva no direito: modos de ser, modos de dizer. 2008. 388 f. Tese (Doutorado em Letras) - Universidade de São Paulo, São Paulo, 2008.

. Do jornalístico ao jurídico e do jurídico ao jornalístico. Estudos Linguísticos, São Paulo, v.3, p.1458-147, 2011.

VOLÓSHINOV,V. N.; BAJTÍN, M. La construcción de la enunciación. In: SLLVESTRI, A.; BLANCK, G. Bajtín y Vigotski: la organización semiótica de la conciencia. Barcelona: Anthropos, 1993. p.245-276. 
VOLÓSHINOV, V. N. El Marxismo y la filosofía del lenguaje: los principales problemas del método sociológico en la ciencia del lenguaje. Buenos Aires: Ediciones Godot, 2009.

VOLOŠINOV, V. N. Marxisme et philosophie du langage: les problèmes fondamentaux de la méthode sociologique dans la science du langage. Nouvelle édition bilingue traduite du russe par Patrick Sériot et Inna Tylkowski-Ageeva. Limoges: Lambert-Lucas, 2010.

Recebido em 09 de setembro de 2011.

Aprovado em 20 de agosto de 2012. 
